\title{
OpenSAFELY: Risks of COVID-19 hospital admission and death for people with learning disabilities - a cohort study.
}

The OpenSAFELY Collaborative, Elizabeth J Williamson ${ }^{1 *}$, Helen I McDonald ${ }^{1 *}$, Krishnan Bhaskaran ${ }^{1}$, Alex J Walker ${ }^{2}$, Sebastian Bacon², Simon Davy², Anna Schultze ${ }^{1}$, Laurie Tomlinson ${ }^{1}$, Chris Bates ${ }^{3}$, Mary Ramsay ${ }^{4}$, Helen J Curtis ${ }^{2}$, Harriet Forbes ${ }^{1}$, Kevin Wing ${ }^{1}$, Caroline Minassian ${ }^{1}$, John Tazare ${ }^{1}$, Caroline E Morton², Emily Nightingale ${ }^{1}$, Amir Mehrkar², Dave Evans ${ }^{2}$, Peter Inglesby ${ }^{2}$, Brian MacKenna ${ }^{2}$, Jonathan Cockburn ${ }^{3}$, Christopher T Rentsch ${ }^{1}$, Rohini Mathur ${ }^{1}$, Angel YS Wong ${ }^{1}$, Rosalind M Eggo ${ }^{1}$, Will Hulme ${ }^{2}$, Richard Croker, John Parry ${ }^{3}$, Frank Hester ${ }^{3}$, Sam Harper ${ }^{3}$, Ian J Douglas ${ }^{1}$, Stephen JW Evans ${ }^{1}$, Liam Smeeth $^{1} \dagger$, Ben Goldacre ${ }^{2 *} \dagger$, Hannah Kuper ${ }^{1} \dagger$

† Joint principal investigators; * joint first authors

${ }^{1}$ London School of Hygiene and Tropical Medicine, Keppel Street, London WC1E 7HT

${ }^{2}$ The DataLab, Nuffield Department of Primary Care Health Sciences, University of Oxford, OX26GG

${ }^{3}$ TPP, TPP House, 129 Low Lane, Horsforth, Leeds, LS18 5PX

${ }^{4}$ Public Health England, London.

${ }^{*}$ Corresponding 
medRxiv preprint doi: https://doi.org/10.1101/2021.03.08.21253112; this version posted March 8, 2021. The copyright holder for this preprint (which was not certified by peer review) is the author/funder, who has granted medRxiv a license to display the preprint in perpetuity.

It is made available under a CC-BY 4.0 International license.

\section{Abstract}

Objectives: To assess the association between learning disability and risk of hospitalisation and mortality from COVID-19 in England among adults and children.

Design: Working on behalf of NHS England, two cohort studies using patient-level data for $>17$ million people from primary care electronic health records were linked with death data from the Office for National Statistics and hospitalization data from NHS Secondary Uses Service using the OpenSAFELY platform.

Setting: General practices in England which use TPP software.

Participants: Participants were males and females, aged up to 105 years, from two cohorts: (1) wave 1, registered with a TPP practice as of $1^{\text {st }}$ March 2020 and followed until $31^{\text {st }}$ August, 2020; (2) wave 2 registered $1^{\text {st }}$ September 2020 and followed until $31^{\text {st }}$ December 2020 (for admissions) or $8^{\text {th }}$ February 2021 (for deaths). The main exposure group was people included on a general practice learning disability register (LDR), with a subgroup of people classified as having profound or severe learning disability. We also identified patients with Down syndrome and cerebral palsy (whether or not on the learning disability register).

Main outcome measures: (i) COVID-19 related death, (ii) COVID-19 related hospitalisation. Non-COVID-19 related death was also explored.

Results: In wave 1, of 14,301,415 included individuals aged 16 and over, 90,095 (0.63\%) were identified as being on the LDR. 30,173 COVID-related hospital admissions, 13,919 COVID-19 related deaths and 69,803 non-COVID deaths occurred; of which 538 (1.8\%), 221 $(1.6 \%)$ and $596(0.85 \%)$ were among individuals on the LDR, respectively. In wave 2, 27,611 COVID-related hospital admissions, 17,933 COVID-19 related deaths and 54,171 nonCOVID deaths occurred; of which 383 (1.4\%), 260 (1.4\%) and $470(0.87 \%)$ were among individuals on the LDR. Wave 1 hazard ratios for individuals on the LDR, adjusted for age, sex, ethnicity and geographical location, were 5.3 (95\% confidence interval $(\mathrm{Cl})$ 4.9, 5.8) for COVID-19 related hospital admissions and 8.2 (95\% Cl: 7.1, 9.4) for COVID-19 related death. Wave 2 produced similar estimates. Associations were stronger among those classed as severe-profound and among those in residential care. Down syndrome and cerebral palsy were associated with increased hazard of both events in both waves; Down syndrome to a much greater extent. Hazards of non-COVID-19 related death followed similar patterns with weaker associations.

Conclusions: People with learning disabilities have markedly increased risks of hospitalisation and mortality from COVID-19. This raised risk is over and above that seen for non-COVID causes of death. Ensuring prompt access to Covid-19 testing and health care and consideration of prioritisation for COVID-19 vaccination and other targeted preventive measures are warranted.

Keywords

Learning disability; COVID-19; risk; mortality; hospitalisation. 
medRxiv preprint doi: https://doi.org/10.1101/2021.03.08.21253112; this version posted March 8, 2021. The copyright holder for this preprint (which was not certified by peer review) is the author/funder, who has granted medRxiv a license to display the preprint in perpetuity.

It is made available under a CC-BY 4.0 International license .

\section{Background}

Identification of high-risk groups for severe outcomes from COVID-19 is critically important in risk stratification, including informing vaccine prioritisation and other targeted preventive measures. People with learning disability, who total more than one million people in England alone or $2 \%$ of the adult population, may be one such vulnerable group ${ }^{1}$. As of February 2021, the Learning from Death Reviews (LeDeR) programme reported that 1405 people with a learning disability had died from COVID-19 in England since February $2020^{2}$. The true number is likely to be far higher due to gaps in registration of learning disability. Emerging evidence from the first wave of the COVID-19 epidemic showed that people with learning disability were at higher risk from mortality ${ }^{3-7}$ compared to others in the population. For instance, the Oxford RCGP Research and Surveillance Centre (RSC) sentinel network reported an odds ratio of 1.96 (95\% confidence interval $(\mathrm{Cl}) 1.22$ to 3.18$)$ for mortality during the first wave of infection in the UK, among people with learning disability compared to those without. ${ }^{4}$ People with Down syndrome may be at particularly high risk; an analysis of primary care data from 8 million adults reported a hazard ratio of $10.4(95 \% \mathrm{Cl} 7.1$ to 15.2$)$ for COVID death associated with Down syndrome. ${ }^{8}$ However, existing studies on the association of learning disability with COVID-19 severe outcomes do not include the second wave of the pandemic, and frequently adjusted for variables which might be on the causal pathway, such as deprivation and comorbidities, complicating interpretation of the results ${ }^{4}$. There is also lack of clarity on the elevated risk of COVID-19 deaths among individuals with milder learning disability, and this needs exploration. ${ }^{9}$

The higher risks of premature death among people with learning disability in England is wellknown, ${ }^{1,10}$ and triggered the establishment of GP Learning Disability registers to allow for better provision of their healthcare. There are a number of mechanisms by which their risk of COVID-19 mortality may also be greater. People with learning disability have a higher prevalence of COVID-19 mortality risk factors, including obesity, diabetes, epilepsy and poverty. ${ }^{11-13}$ Medical conditions underlying the learning disability may confer additional risk; for instance, people with Down syndrome are more vulnerable to immune dysregulation, congenital heart disease and respiratory conditions ${ }^{14}$. Many people with learning disability in England live in residential care or receive community based social care, and therefore have frequent contact with carers and other care recipients and face challenges in physical distancing. Difficulties understanding protective measures needed, compounded by lack of accessible information, further increases their vulnerability to infection. Healthcare access and quality, including prevention and treatment, is frequently worse for people with learning disability, and leads to avoidable deaths. ${ }^{10}$ Treatment failures ${ }^{10}$, including do not resuscitate orders $^{15}$, may increase their risk of death once infected.

Until February 24, 2021, the national recommendations for prioritisation of COVID-19 vaccination in England included all adults with cerebral palsy, severe or profound learning disability, Down syndrome, and the whole resident population in care settings where a high proportion of residents would be eligible for vaccination (for example due to learning disability). ${ }^{16,17}$ Consequently, not everyone on the Learning Disability registers was eligible for COVID-19 vaccination, in particular people with mild to moderate learning disability from causes other than Down syndrome or cerebral palsy who are not living in residential care. 
medRxiv preprint doi: https://doi.org/10.1101/2021.03.08.21253112; this version posted March 8, 2021. The copyright holder for this preprint (which was not certified by peer review) is the author/funder, who has granted medRxiv a license to display the preprint in perpetuity.

It is made available under a CC-BY 4.0 International license .

This work was undertaken rapidly in response to an urgent need to inform policy-making on vaccination prioritisation in the UK and elsewhere.

The aim of this study is to use linked electronic health records within the OpenSAFELY platform to rapidly describe the risk of COVID-19 related hospitalisation and mortality among children and adults in England with learning disability compared to the general population. A subsidiary aim is to separate the risk by types of learning disability (severe-profound; cerebral palsy, Down syndrome, learning disability register), including people with learning disability not originally included in the first 6 priority groups of the Phase 1 vaccination priority list in the UK. 
medRxiv preprint doi: https://doi.org/10.1101/2021.03.08.21253112; this version posted March 8, 2021. The copyright holder for this preprint (which was not certified by peer review) is the author/funder, who has granted medRxiv a license to display the preprint in perpetuity.

It is made available under a CC-BY 4.0 International license.

\section{Methods}

\section{Study design}

Two population-based observational cohort studies of patients in England were performed using data within the OpenSAFELY platform.

\section{Data}

We used data from primary care linked to secondary care and mortality records in England. Records were linked to the NHS England inpatient activity data sets from Secondary Uses Service (SUS) data extracts including data from inpatient activity data sets for ascertaining COVID-related hospitalisations ${ }^{18}$; and Office for National Statistics (ONS) death data for ascertaining COVID-19 related deaths. The dataset analysed within OpenSAFELY is based on 24 million people currently registered with GP surgeries using TPP SystmOne software, approximately $40 \%$ of the population in England. All data is pseudonymized and includes coded diagnoses (using Read version 3, CTV3 codes), medications and physiological parameters. No free text data are included.

\section{Study population}

The first cohort comprised patients (males and females, aged up to 105 years) registered as of $1^{\text {st }}$ March 2020 in a general practice which employs the TPP system and followed until $31^{\text {st }}$ August, 2020. Patients with missing age or a recorded age over 105 years, missing gender, or missing postcode (from which much of the household and geographic information is calculated) were excluded. The second cohort were similarly defined, but included patients registered as of $1^{\text {st }}$ September 2020 in a general practice which employs the TPP system and followed until $31^{\text {st }}$ December 2020 (admissions) or $8^{\text {th }}$ February 2021 (deaths). Membership of the two cohorts may differ slightly due to patients leaving and joining TPP practices and to patients dying prior to the second cohort. These two time periods correspond to the two main "waves" of COVID-19 infection experienced in England during $2020 .^{19}$ In particular, the 1 st September 2020 had the lowest number of COVID-19 related deaths since the start of the pandemic. ${ }^{20}$

\section{Exposures}

All codelists used to define exposure groups are provided online, with links given in the Supplementary Materials. The main exposure group was individuals on the learning disability register. This register contains a subset of individuals with learning disability; it is not a comprehensive list. However, the register provides a simple and practical means of identifying people for vaccine prioritisation or implementation of other public health measures. A subset of the codes used to define the learning disability register classified the learning disability as severe or profound, and were used to class a subset of individuals as having severe or profound learning disability. 
medRxiv preprint doi: https://doi.org/10.1101/2021.03.08.21253112; this version posted March 8, 2021. The copyright holder for this preprint (which was not certified by peer review) is the author/funder, who has granted medRxiv a license to display the preprint in perpetuity.

It is made available under a CC-BY 4.0 International license .

Due to the absence of a comprehensive indicator of residential care, individuals living in a household containing at least five individuals identified as being on the learning disability register were classed as being in residential care. Households were identified based on GP registered addresses as of 1 st February 2020, standardised and corrected using publicly available house sale data to remove registrations which are likely not current. We use the term "residential care" throughout, although we note that this includes a range of settings (care homes, educational settings, sheltered accommodation, etc.) and there is likely to be misclassification.

Individuals with Down syndrome and cerebral palsy were identified based on GP codes (details in Supplementary Materials).

\section{Outcomes}

The outcomes for this study are (i) COVID-19 related death (defined as a COVID-19 ICD-10 code of U07.1 or U07.2 anywhere on the death certificate - ascertained from ONS death certificate data)) and (ii) COVID-19 related hospitalisation (defined as admissions with any ICD-10 admission diagnosis (not restricted to primary diagnosis) of U07.1 or U07.2 ascertained from SUS data). Individuals who experienced a COVID-19 related hospitalisation and then a death contributed to both outcomes. An additional outcome of non-COVID-19 related death was also considered (ascertained from ONS death certificate data, excluding deaths classed as COVID-19 related).

\section{Covariates}

Covariates included demographics (age, sex, ethnicity and geographical area), which could act as potential confounders, and deprivation (index of multiple deprivation) as a potential confounder and/or mediator. To consider mediation by physical comorbidities that are also indications for vaccination we included body mass index $>40 \mathrm{~kg} / \mathrm{m} 2$, chronic cardiac disease, atrial fibrillation, deep vein thrombosis/pulmonary embolism, diabetes (further grouped by level of control, as measured by the latest $\mathrm{HbA1c}$ measurement), chronic liver disease, stroke, transient ischaemic attack, dementia, asthma requiring use of oral corticosteroids, other chronic respiratory disease, reduced kidney function, dialysis, organ transplant, asplenia, other conditions leading to immunosuppression, and haematological cancer. We also included non-haematological cancer diagnosed in the last year, rheumatoid arthritis/lupus/psoriasis, and inflammatory bowel disease as common indications for immunosuppressing medication. These aim to map to the existing physical indications for vaccination among 16-64 year olds in England; however data on epilepsy was not available for this analysis. To exclude individuals already prioritised for vaccination we additionally ascertained other neurological conditions and serious mental illness. These measures were obtained from medical records (details in Supplementary Materials).

\section{Statistical methods}

Analysis was undertaken separately for adults 16 years and over and children under 16 . The three analysis steps below were repeated for the following exposures: being on the learning 
medRxiv preprint doi: https://doi.org/10.1101/2021.03.08.21253112; this version posted March 8, 2021. The copyright holder for this preprint (which was not certified by peer review) is the author/funder, who has granted medRxiv a license to display the preprint in perpetuity.

It is made available under a CC-BY 4.0 International license .

disability register (all, then divided into severe-profound versus mild-moderate and residential care versus non-residential care), Down syndrome and cerebral palsy.

The two cohorts, for each wave, were analysed separately. Analysis used Cox proportional hazards model for (i) COVID-19 related mortality and (ii) COVID-19 related hospital admission, stratified by local geographical area, as measured by the Sustainability and Transformation Partnership, to account for differing patterns of infection over time in different regions, with days in study as the timescale. Follow-up was censored at competing events (non-COVID death for mortality analyses and any death for hospital admission analyses) to target the cause-specific hazard. Models adjusted for confounders (age, sex, ethnicity), additionally for deprivation, residential care status and physical comorbidities (described above), and then adjusted for all of these factors simultaneously. Exposure interactions with broad age strata $(16-<65,65-<75,75+)$ were explored.

Similar Cox models were fitted for COVID-19 related hospital admission, after excluding individuals who were already prioritised for vaccination due to age or comorbidities, as part of the first 6 priority groups of Phase I in the UK. These were individuals 65 years and over and individuals with codes for physical conditions indicating priority for vaccination described above, other neurological conditions, severe mental illness, Down syndrome, cerebral palsy, and severe-profound learning disability. These Cox models adjusted for the confounders, then separately for deprivation and residential care status.

Finally, Cox models for non-COVID-19 related death were fitted, adjusting for the same variables as previous models.

For children under 16 years, these analyses were undertaken separately, omitting analyses looking at COVID-19 related death and full adjustment for comorbidities due to much smaller numbers of outcomes.

\section{Missing data}

A complete case approach was taken to missing ethnicity data ( $25 \%$ of records). Previous analyses in these data suggest the assumption required for complete case analysis - that missingness is unrelated to outcome given covariates - are approximately satisfied here ${ }^{12}$. Individuals with missing BMI were assumed to be non-obese. Patients with no serum creatinine measurement were included in the "no evidence of poor kidney function". Patients with diabetes but no Hba1c measurement were included in a separate "diabetes, no Hba1c" category.

\section{Software and Reproducibility}

The pre-specified study protocol is archived with version control

(https://github.com/opensafely/Published-

Protocols/blob/master/Learning Disability Covid Protocol $2021 \quad 10$ 02.pdf) 
medRxiv preprint doi: https://doi.org/10.1101/2021.03.08.21253112; this version posted March 8, 2021. The copyright holder for this preprint (which was not certified by peer review) is the author/funder, who has granted medRxiv a license to display the preprint in perpetuity.

It is made available under a CC-BY 4.0 International license.

\section{Patient and Public Involvement}

We have developed a publicly available website https://opensafely.org/ through which we invite any patient or member of the public to contact us regarding this study or the broader OpenSAFELY project. 
medRxiv preprint doi: https://doi.org/10.1101/2021.03.08.21253112; this version posted March 8, 2021. The copyright holder for this preprint (which was not certified by peer review) is the author/funder, who has granted medRxiv a license to display the preprint in perpetuity.

It is made available under a CC-BY 4.0 International license .

\section{Results}

Table 1 shows the baseline characteristics of individuals aged 16 and over included in the analysis and Table 2 shows characteristics of those under 16 years old (characteristics in wave 2 were very similar).

Among 14,301,415 included individuals aged 16 or over, $90,095(0.63 \%)$ were identified as being on the learning disability register (Table 1). Of these, 16,115 (18\%) were identified as having severe-profound learning disability, and 8,027 (9\%) as being in residential care.

8,022 individuals were identified as having Down syndrome, of whom 7124 (89\%) were on the learning disability register. 18,264 individuals were identified as having cerebral palsy, of whom $6,913(38 \%)$ were on the learning disability register. Those on the learning disability register were more likely to be male, younger and living in more deprived areas.

Comorbidities were fairly similar across groups, with more diabetes, obesity, other neurological disease, and diagnoses of serious mental illness among those on the learning disability register.

Among 2,624,353 included individuals under 16 years (Table 2), 9,114 (0.35\%) were identified as being on the learning disability register. Of the 2,635 individuals identified as having Down syndrome, only 907 (34\%) were identified as being on the learning disability register. Of the 4,619 individuals identified as having cerebral palsy, $500(11 \%)$ were identified as being on the learning disability register.

\section{COVID-19 related hospital admissions and deaths}

Among individuals 16 years and older during wave 1 (1 March 2020 - 31 August 2020; 183 days), 30,173 COVID-related hospital admissions occurred, 538 (1.8\%) among individuals on the learning disability register; 13,919 COVID-19 related deaths occured, 221 (1.6\%) among individuals on the learning disability register (Table 3). 69,803 non-COVID deaths occurred, $596(0.85 \%)$ among individuals on the learning disability register.

In wave 2 (1 September 2020 - 31 December 2020 (admissions) or 8 February 2021 (death); 121 and 160 days, respectively), 27,611 COVID-related hospital admissions occurred, 383 (1.4\%) among individuals on the learning disability register; 17,933 COVID-19 related deaths occured, 260 (1.4\%) among individuals on the learning disability register. 54,171 non-COVID deaths occurred, $470(0.87 \%)$ among individuals on the learning disability register.

Figure 1 shows cumulative COVID-19 related mortality and hospital admissions during the study period, accounting for sex, age and ethnicity for individuals on the learning disability register and those not. Both graphs show a clear increase in events among those on the learning disability register, with a flattening off apparent during the period between waves of infection.

Among individuals under 16 years of age, 281 COVID-19 related hospital admissions occurred in wave 1 and 292 in wave 2 . These numbers cannot be split by learning disability status due to stringent redaction rules applied to protect patient privacy. 
medRxiv preprint doi: https://doi.org/10.1101/2021.03.08.21253112; this version posted March 8, 2021. The copyright holder for this preprint (which was not certified by peer review) is the author/funder, who has granted medRxiv a license to display the preprint in perpetuity.

It is made available under a CC-BY 4.0 International license .

\section{Hazard ratios for COVID-19 hospital admission and death}

Adjusted for age, sex, ethnicity and geographical location, the estimated hazard ratio for COVID-19 related hospital admission in wave 1 was 5.3 (95\% confidence interval $(\mathrm{Cl})$ 4.9, 5.8) for individuals on the learning disability register (Table 3). For COVID-19 related death, the hazard ratio was 8.2 (95\% Cl: 7.1, 9.4). Wave 2 produced similar estimates (HR for COVID-19 related hospital admission $3.6(95 \% \mathrm{Cl} 3.3,4.0)$, HR for COVID-19 related death $7.4(95 \% \mathrm{Cl} 6.5,8.4))$. These associations were stronger among those classed as severeprofound and among those in residential care. Down syndrome was associated with greatly increased hazard of both events in both waves, (wave $1 \mathrm{HR}$ for COVID-19 related hospital admission 10.6 (95\% Cl 8.5, 13.2), wave $1 \mathrm{HR}$ for COVID-19 related death $36.0(95 \% \mathrm{CI}$ 26.4, 49.0; similar numbers for wave 2). Cerebral palsy was associated with higher hazards to a lesser extent (wave $1 \mathrm{HR}$ for COVID-19 related hospital admission 4.9 (95\% Cl 3.8, 6.3), wave $1 \mathrm{HR}$ for COVID-19 related death 5.9 (95\% $\mathrm{Cl} 4.1$, 8.3; similar numbers for wave 2).

Further adjustment for deprivation, residential care and physical comorbidities only slightly attenuated these associations (Supplementary tables). The confounder-adjusted hazard ratio for wave 1 COVID-19 related hospital admission for being on the learning disability register, HR $5.3(95 \% \mathrm{Cl} 4.9,5.8)$, reduced to $3.9(95 \% \mathrm{Cl} 3.6,4.3)$ after full adjustment. In Down syndrome, however, adjustment for both residential care and comorbidities greatly attenuated hazard ratios (for example, the wave 1 hazard ratio for COVID-19 related hospital admission reduced from $10.6(95 \% \mathrm{Cl} 8.5,13.2)$ to $6.3(95 \% \mathrm{Cl} 4.9,8.2)$ after adjustment for residential care and $7.2(95 \% \mathrm{Cl} 5.8,9.0)$ after adjustment for physical comorbidities and $4.64(95 \% \mathrm{Cl} 3.6,6.0)$ after adjusted for all.

\section{Hazard ratios for COVID-19 hospital admission among those under 16}

Among individuals under 16 years old, being on the learning disability register was associated with increased hazard of COVID-19 related hospital admissions (wave 1 HR 5.1 (95\% Cl 1.9, 14.0), wave 2 HR 8.8 (95\% Cl 4.9, 15.8), Supplementary Tables).

\section{Effect modification by age}

In wave 1, an interaction was observed between being on the learning disability register and age, on the hazard of COVID-19 related death, with those $16-<65$ having a hazard ratio 12.3 (95\% Cl 10.0, 15.1), 65-<75 HR 10.1 (8.3, 13.3) and 75+ HR 4.2 (95\% Cl 3.2, 5.5), with similar estimates seen for wave 2. A similar interaction was not observed for COVID-19 related hospital admission in either wave.

\section{Hazard ratios among individuals not prioritised for vaccination}

After excluding people 65 years and older and those with comorbidities listed above, the estimated hazard ratio of COVID-19 related hospital admission was 6.7 (95\% Cl 1.6, 28.2) after adjustment for age, sex, ethnicity and geographical location, with little change after adjustment for deprivation or residential care status. Too few events were observed to analyse finer groupings or wave 2 events. 
medRxiv preprint doi: https://doi.org/10.1101/2021.03.08.21253112; this version posted March 8, 2021. The copyright holder for this preprint (which was not certified by peer review) is the author/funder, who has granted medRxiv a license to display the preprint in perpetuity.

It is made available under a CC-BY 4.0 International license.

\section{Hazard ratios for non-COVID-19 death}

Adjusted for age, sex, ethnicity and geographical location, the estimated hazard ratio for non-COVID-19 related death was $3.7(95 \% \mathrm{Cl} 3.4,4.0)$ in wave 1 and $3.9(3.6,4$.$) in wave 2$. Associations were stronger among those classed as having severe-profound learning disability. Associations were slightly stronger among those classed as being in residential care. Down syndrome was associated with a greatly increased hazard of non-COVID-19 related death (wave $1 \mathrm{HR} 12.3(95 \% \mathrm{Cl} 10.0,15.2$; similar numbers for wave 2). Cerebral palsy was associated with higher hazards to a lesser extent (wave 1 HR for COVID-19 related death $3.2(95 \% \mathrm{Cl} 2.6,4.0$; similar numbers for wave 2). 
medRxiv preprint doi: https://doi.org/10.1101/2021.03.08.21253112; this version posted March 8, 2021. The copyright holder for this preprint (which was not certified by peer review) is the author/funder, who has granted medRxiv a license to display the preprint in perpetuity.

It is made available under a CC-BY 4.0 International license.

\section{Discussion}

Our data show a higher risk of hospitalisation and deaths for all the groups with learning disability relative to comparators. Generally, the pattern of hazard ratios is consistent for waves 1 and 2, and hospitalisations and deaths. Hazard ratios appear slightly lower for wave 2 than wave 1 for both hospitalisations and deaths. Higher risks were observed among those with severe-profound learning disability compared to mild-moderate, which was not explained by measured physical comorbidities or residential care status. However, the absolute number of deaths was higher among people with mild-moderate learning disability. For Down Syndrome and cerebral palsy, we observed higher risk among those on the learning disability register. Higher risk remains among those on the learning disability register who do not have Down syndrome or cerebral palsy, compared to the general population. This is not explained by measured physical comorbidities or residential care status. After excluding people who were prioritised for vaccination among groups 1-6 of Phase I in England due to reasons of age or comorbidity, those on the learning disability register had a remaining substantial increased risk of COVID-19 related hospital admission. Higher risks of non-COVID-19 related deaths were also observed in people with learning disabilities, though associations were much less strong than for COVID-19 death; this is in contrast with most other risk factors which appear to have a similar magnitude of association with both COVID-19 related and non-COVID-19 related death ${ }^{21}$.

\section{Findings in context}

Our findings are consistent with the existing literature. The Oxford RCGP Research and Surveillance Centre sentinel network, including 4.4 million people nationally representative from England, reported two-fold higher mortality among people with learning disability (OR 1.96, $95 \% \mathrm{Cl} 1.22,3.18, \mathrm{p}<0.01$ ) after extensive adjustment ${ }^{4}$. Public Health England used different sources of data and estimated that, up to June 2020, people with learning disability had approximately 6.3 times the mortality rate as the general population ${ }^{22}$. Overall, COVID19 was responsible for at least half of deaths among people with learning disability during this period. Data from Scotland also showed that adults with intellectual disabilities had higher rates of COVID-19 infection, severe infection and mortality ${ }^{5}$. Elevated risks remained after adjusting for age, sex and deprivation (Standardised severe infection ratio: 2.59, 95\% Cl 1.80, 3.39; Standardised mortality ratio $3.2095 \% \mathrm{Cl} 2.1,4.25)$. Higher mortality rate among people with learning disability has also been demonstrated in Wales ${ }^{6}$, New York State $^{7}$, and the USA more broadly ${ }^{3}$. Not only are death rates higher for people with learning disability, but deaths occur at younger ages ${ }^{3,8,9,22}$. Indeed, the particularly elevated mortality rates among younger people with learning disability noted in our study have also been reported in the $U_{S A}^{3}$.

The particularly high risk for people with Down Syndrome was demonstrated for the first wave by Clift and colleagues using the QResearch population level primary care database ${ }^{8}$. In their cohort of 8 million adults in England from January to June 2020, the age- and sexadjusted hazard ratio for COVID-19 death for adults with versus without Down syndrome was $24.94(95 \% \mathrm{Cl} 17.08,36.44)$, which reduced to $10.39(95 \% \mathrm{Cl} 7.08,15.23)$ after extensive adjustment (deprivation, BMI, cardiovascular, pulmonary and other disease, residential status, ethnicity). Data for cerebral palsy is more limited, but the QResearch analyses showed a higher mortality rate for this group $(2.66,95 \% \mathrm{Cl} 1.62,4.36)$. Clift and 
medRxiv preprint doi: https://doi.org/10.1101/2021.03.08.21253112; this version posted March 8, 2021. The copyright holder for this preprint (which was not certified by peer review) is the author/funder, who has granted medRxiv a license to display the preprint in perpetuity.

It is made available under a CC-BY 4.0 International license .

colleagues obtained a fully adjusted hazard ratio of 1.27 (95\% CI 1.16, 1.40) for COVID-19 death in those with learning disabilities other than Down syndrome, in contrast to our higher estimates. This discrepancy is likely due to differences in adjustment. We chose not to adjust for many comorbidities, viewing many of these as consequences of the learning disability thus part of the causal pathway. In our analyses, children with learning disability had a higher risk of hospital admission for COVID-19, notwithstanding the extremely small numbers. Similarly, existing studies also indicate that children with learning disability are more vulnerable to requiring hospitalization and critical care due to COVID-19 outcomes ${ }^{23-26}$. Evidence on mortality remains lacking for children.

The hazard rates for COVID-19 outcomes in our study attenuated after adjustment for deprivation. Residential status also partially explained the higher risks of severe COVID-19 outcomes in people with learning disability. However, residential care for people with learning disability may not raise risk as much as in other care settings, perhaps because there are generally fewer beds ${ }^{22}$ in these facilities. An important driver appears to be comorbidities, reflecting the higher prevalence of these COVID-19 risk factors among people with learning disability ${ }^{11,13}$. However, large excess mortality rates remained after extensive adjustment, as is also apparent in previous studies ${ }^{8}$. This pattern implies that other drivers may be relevant, including inherent clinical vulnerabilities for people with certain conditions and concerns about healthcare quality, as also indicated by the higher case fatality rates among people with learning disability (Scotland: $30 \%$ versus $24 \%{ }^{5}$; New York: $15,0 \%$ versus $7.9 \%^{7}$; USA $18-74$ year olds: $4.5 \%$ versus $2.7 \%^{3}$ ).

\section{Strengths and weaknesses}

Key strengths and weaknesses of the OpenSafely platform have been outlined previously ${ }^{12}$. An important strength for the current analyses is that the study is large, including records of approximately $40 \%$ of the English population, allowing disaggregation by learning disability grouping. We had comprehensive data on participants from medical records, allowing us to adjust analyses successively to explore mechanisms for the association of learning disability and adverse COVID-19 outcomes. Furthermore, we were able to assess excess risks in both waves 1 and 2 of the COVID-19 epidemic, in terms of both hospitalization and mortality outcomes. We considered children as well as adults.

There are also important limitations. It is not possible to identify everyone with a learning disability from medical records alone, which may have under-estimated hazard ratios. For instance, the most recent data, from 2015 , suggests that $23 \%$ of people with learning disability are included on the registers ${ }^{1}$. Our hospitalisation data included only completed hospital admissions, thus will have under-ascertained this outcome towards the end of wave 2. Data was not available on epilepsy, which is both a COVID-19 risk factor and more common among people with learning disability ${ }^{11,13}$. We also had an incomplete measure of residential care. There was missing data, in particular for ethnicity, although we do not anticipate that this had a meaningful impact on the results. We did not have data on quality of treatment and so were not able to explore all our hypothesised pathways between learning disability and adverse COVID-19 outcomes. Furthermore, these analyses focussed only on severe COVID-19 outcomes, and did not explore impacts on physical and mental health of people with learning disability which are likely to occur as a result of lockdown and other restrictions ${ }^{23}$ and require mitigation. We focused on the general population, so our analyses explore the combination of infection and severe outcomes once infected, thus we 
medRxiv preprint doi: https://doi.org/10.1101/2021.03.08.21253112; this version posted March 8, 2021. The copyright holder for this preprint (which was not certified by peer review) is the author/funder, who has granted medRxiv a license to display the preprint in perpetuity.

It is made available under a CC-BY 4.0 International license .

are unable to disentangle associations with those two steps in the process. However, focusing on the infected only would induce biases due to unrepresentative testing.

Policy implications and interpretation

In February, 2021, the Joint Committee on Vaccination and Immunisation updated its guidance $^{27}$ to include everyone on the Learning disability registers, as well as people with Down Syndrome, cerebral palsy or in residential care, as priority groups to receive the vaccine. This change was informed by a prior version of this analysis, demonstrating the increased risk in the remaining group. The current Learning Disability registers are incomplete ${ }^{1}$, however, and updating them will facilitate this and future prioritization exercises. Many other countries (e.g. Germany ${ }^{28}, U_{S A^{29}}$ ) currently focus on prioritizing people living in care homes and those with Down Syndrome for vaccination, and should consider broadening this category to include other people with learning disability. Raised risks seen among those under 16 years suggest that vaccination in this age group warrants further consideration. Besides vaccination, efforts should continue to protect people with learning disability from COVID-19 adverse outcomes, including through consideration of non-pharmacological interventions such as shielding, and ensuring adequate support to obtain prompt access to testing for Covid-19 and to appropriate health care.

\section{Future Research}

The ONS data shows that people with disabilities in general are at higher risk of COVID-19 mortality ${ }^{30}$, but this has not yet been explored through the clinical databases, in part because of the complexity of generating codelists for these broad range of conditions. The example of the Learning Disability register data has, however, highlighted the importance of public health surveillance and the need to develop indicators for disability. More research is warranted on the excess COVID-19 risks among people with Down Syndrome. Cerebral palsy includes people with a broad range of conditions and severity, and a deeper exploration or COVID-19 risk for this group is warranted.

\section{Conclusion}

People with learning disabilities have markedly increased risks of hospitalisation and death from COVID-19. Ensuring prompt access to Covid-19 testing and health care and consideration of prioritisation for COVID-19 vaccination and other targeted preventive measures are warranted. 
medRxiv preprint doi: https://doi.org/10.1101/2021.03.08.21253112; this version posted March 8, 2021. The copyright holder for this preprint (which was not certified by peer review) is the author/funder, who has granted medRxiv a license to display the preprint in perpetuity.

It is made available under a CC-BY 4.0 International license .

\section{Administrative}

\section{Acknowledgements}

This work uses data provided by patients and collected by the NHS as part of their care and support. We are very grateful for all the support received from the TPP Technical Operations team throughout this work, and for generous assistance from the information governance and database teams at NHS England / NHSX.

\section{Conflicts of Interest}

All authors have completed the ICMJE uniform disclosure form at www.icmje.org/coi_disclosure.pdf and declare the following: BG has received research funding from the Laura and John Arnold Foundation, the NHS National Institute for Health Research (NIHR), the NIHR School of Primary Care Research, the NIHR Oxford Biomedical Research Centre, the Mohn-Westlake Foundation, NIHR Applied Research Collaboration Oxford and Thames Valley, the Wellcome Trust, the Good Thinking Foundation, Health Data Research UK (HDRUK), the Health Foundation, and the World Health Organization; he also receives personal income from speaking and writing for lay audiences on the misuse of science. IJD has received unrestricted research grants and holds shares in GlaxoSmithKline (GSK).

\section{Funding}

This work was supported by the Medical Research Council MR/V015737/1. TPP provided technical expertise and infrastructure within their data centre pro bono in the context of a national emergency. EW was supported by MRC project grant MR/S01442X/1. BG's work on better use of data in healthcare more broadly is currently funded in part by: NIHR Oxford Biomedical Research Centre, NIHR Applied Research Collaboration Oxford and Thames Valley, the Mohn-Westlake Foundation, NHS England, and the Health Foundation; all DataLab staff are supported by BG's grants on this work. LS reports grants from Wellcome, MRC, NIHR, UKRI, British Council, GSK, British Heart Foundation, and Diabetes UK outside this work. JPB is funded by a studentship from GSK. AS is employed by LSHTM on a fellowship sponsored by GSK. KB holds a Sir Henry Dale fellowship jointly funded by Wellcome and the Royal Society. HIM is funded by the National Institute for Health Research (NIHR) Health Protection Research Unit in Immunisation, a partnership between Public Health England and LSHTM. AYSW holds a fellowship from BHF. RM holds a Sir Henry Wellcome fellowship. ID holds grants from NIHR and GSK. RM holds a Sir Henry Wellcome Fellowship funded by the Wellcome Trust. HF holds a UKRI fellowship. RME is funded by HDR-UK and the MRC. HK receives funding from the PENDA grant from FCDO

The views expressed are those of the authors and not necessarily those of the NIHR, NHS England, Public Health England or the Department of Health and Social Care. 
medRxiv preprint doi: https://doi.org/10.1101/2021.03.08.21253112; this version posted March 8, 2021. The copyright holder for this preprint (which was not certified by peer review) is the author/funder, who has granted medRxiv a license to display the preprint in perpetuity.

It is made available under a CC-BY 4.0 International license.

Funders had no role in the study design, collection, analysis, and interpretation of data; in the writing of the report; and in the decision to submit the article for publication.

\section{Data sharing}

All data were linked, stored and analysed securely within the OpenSAFELY platform https://opensafely.org/. Data include pseudonymized data such as coded diagnoses, medications and physiological parameters. No free text data are included. All code is shared openly for review and re-use under MIT open license

(https://github.com/opensafely/absolute-risks-covid-research). Detailed pseudonymised patient data is potentially re-identifiable and therefore not shared. We rapidly delivered the OpenSAFELY data analysis platform without prior funding to deliver timely analyses on urgent research questions in the context of the global Covid-19 health emergency: now that the platform is established we are developing a formal process for external users to request access in collaboration with NHS England; details of this process will be published shortly on OpenSAFELY.org.

\section{Information governance and ethical approval}

NHS England is the data controller; TPP is the data processor; and the key researchers on OpenSAFELY are acting on behalf of NHS England. This implementation of OpenSAFELY is hosted within the TPP environment which is accredited to the ISO 27001 information security standard and is NHS IG Toolkit compliant; ${ }^{31,32}$ patient data has been pseudonymised for analysis and linkage using industry standard cryptographic hashing techniques; all pseudonymised datasets transmitted for linkage onto OpenSAFELY are encrypted; access to the platform is via a virtual private network (VPN) connection, restricted to a small group of researchers; the researchers hold contracts with NHS England and only access the platform to initiate database queries and statistical models; all database activity is logged; only aggregate statistical outputs leave the platform environment following best practice for anonymisation of results such as statistical disclosure control for low cell counts. ${ }^{33}$ The OpenSAFELY research platform adheres to the obligations of the UK General Data Protection Regulation (GDPR) and the Data Protection Act 2018. In March 2020, the Secretary of State for Health and Social Care used powers under the UK Health Service (Control of Patient Information) Regulations 2002 (COPI) to require organisations to process confidential patient information for the purposes of protecting public health, providing healthcare services to the public and monitoring and managing the COVID-19 outbreak and incidents of exposure; this sets aside the requirement for patient consent. ${ }^{34}$ Taken together, these provide the legal bases to link patient datasets on the OpenSAFELY platform. GP practices, from which the primary care data are obtained, are required to share relevant health information to support the public health response to the pandemic, and have been informed of the OpenSAFELY analytics platform.

This study was approved by the Health Research Authority (REC reference 20/LO/0651) and by the LSHTM Ethics Board (reference 21863).

\section{Guarantor}

$B G$ is guarantor. 
medRxiv preprint doi: https://doi.org/10.1101/2021.03.08.21253112; this version posted March 8, 2021. The copyright holder for this preprint (which was not certified by peer review) is the author/funder, who has granted medRxiv a license to display the preprint in perpetuity.

\section{Contributorship}

B.G. conceived the platform and the approach; B.G. and L.S. led the project overall and are guarantors. Contributions are as follows: analysis, E.W., H.I.M., H.K., S.E.; data curation, C.B., J.P., J.C., S.H., S.B., D.E., P.I. and C.E.M.; analysis, E.J.W., K.B., A.J.W. and C.E.M.; funding acquisition, B.G. and L.S.; information governance, A.M., B.G., C.B. and J.P.; methodology, E.W., H.I.M., H.K., S.E, K.B., A.J.W., B.G., L.S., C.B., J.P., J.C., S.H., S.B., D.E., P.I., C.E.M.; disease category conceptualization and codelists, C.E.M., A.J.W., P.I., S.B., D.E., C.B., J.C., J.P., S.H., H.J.C., K.B., S.B., A.M., B.M., L.T., I.J.D., H.I.M., R.M. and H.F.; ethics approval, H.J.C., E.J.W., L.S. and B.G.; project administration, C.E.M., H.J.C., C.B., S.B., A.M., L.S. and B.G.; resources, B.G., L.S. and F.H.; software, S.B., D.E., P.I., A.J.W., C.E.M., S.D., C.B., F.H., J.C. and S.H.; supervision, B.G., L.S. and S.B.; writing (original draft), E.J.W., H.K., H.I.M, S.E. All authors were involved in design and conceptual development and reviewed and approved the final manuscript.

All authors contributed to and approved the final manuscript. 
medRxiv preprint doi: https://doi.org/10.1101/2021.03.08.21253112; this version posted March 8, 2021. The copyright holder for this preprint (which was not certified by peer review) is the author/funder, who has granted medRxiv a license to display the preprint in perpetuity.

It is made available under a CC-BY 4.0 International license .

\section{References}

1. Public Health England. People with Learning Disabilities in England 2015. Published November 29, 2016. Accessed March 3, 2020.

https://www.gov.uk/government/publications/people-with-learning-disabilities-inengland-2015

2. Notification to LeDeR (Learning from death reviews) programme. https://www.england.nhs.uk/publication/covid-19-deaths-of-patients-with-a-learningdisability-notified-to-leder/

3. Turk MA, Landes SD, Formica MK, Goss KD. Intellectual and developmental disability and COVID-19 case-fatality trends: TriNetX analysis. Disabil Health J. 2020;13(3):100942-100942. doi:10.1016/j.dhjo.2020.100942

4. Joy M, Hobbs FR, Bernal JL, et al. Excess mortality in the first COVID pandemic peak: cross-sectional analyses of the impact of age, sex, ethnicity, household size, and longterm conditions in people of known SARS-CoV-2 status in England. Br J Gen Pract. 2020;70(701):e890. doi:10.3399/bjgp20X713393

5. Henderson A, Fleming M, Cooper S-A, et al. COVID-19 infection and outcomes in a population-based cohort of 17,173 adults with intellectual disabilities compared with the general population. medRxiv. Published online January 1, 2021:2021.02.08.21250525. doi:10.1101/2021.02.08.21250525

6. Watkins A. COVID-19-Related Deaths in Wales amongst People with Learning Disabilities from 1st March to 26th May 2020. Improvement Cymru; 2020. Accessed March 3, 2020. https://phw.nhs.wales/publications/publications1/covid-19-relateddeaths-in-wales-amongst-people-with-learning-disabilities/

7. Landes SD, Turk MA, Formica MK, McDonald KE, Stevens JD. COVID-19 outcomes among people with intellectual and developmental disability living in residential group homes in New York State. Disabil Health J. 2020;13(4):100969. doi:10.1016/j.dhjo.2020.100969

8. Clift AK, Coupland CAC, Keogh RH, Hemingway H, Hippisley-Cox J. COVID-19 Mortality Risk in Down Syndrome: Results From a Cohort Study Of 8 Million Adults. Ann Intern Med. Published online October 21, 2020. doi:10.7326/M20-4986

9. Perera B, Laugharne R, Henley W, et al. COVID-19 deaths in people with intellectual disability in the UK and Ireland: descriptive study. BJPsych Open. 2020;6(6):e123. doi:10.1192/bjo.2020.102

10. Heslop P, Blair PS, Fleming P, Hoghton M, Marriott A, Russ L. The Confidential Inquiry into premature deaths of people with intellectual disabilities in the UK: a populationbased study. The Lancet. 2014;383(9920):889-895. doi:10.1016/S01406736(13)62026-7

11. Emerson E, Hatton C, Baines S, Robertson J. Emerson E, Hatton C, Baines S, Robertson J. The physical health of British adults with intellectual disability: cross sectional study. Int J Equity Health. 2016;20(15):11. doi:10.1186/s12939-016-0296-x.

12. Williamson EJ, Walker AJ, Bhaskaran $\mathrm{K}$, et al. OpenSAFELY: factors associated with COVID-19 death in 17 million patients. Nature. Published online July 8, 2020. doi:10.1038/s41586-020-2521-4

13. Kinnear D, Morrison J, Allan L, Henderson A, Smiley E, Cooper S-A. Prevalence of physical conditions and multimorbidity in a cohort of adults with intellectual disabilities with and without Down syndrome: cross-sectional study. BMJ Open.

2018;8(2):e018292. doi:10.1136/bmjopen-2017-018292

14. Dard R, Janel N, Vialard F. COVID-19 and Down's syndrome: are we heading for a disaster? Eur J Hum Genet. 2020;28(11):1477-1478. doi:10.1038/s41431-020-0696-7

15. Tapper J. Fury at 'do not resuscitate' notices given to Covid patients with learning disabilities. Published February 13, 2021. Accessed March 3, 2021. https://www.theguardian.com/world/2021/feb/13/new-do-not-resuscitate-orders- 
medRxiv preprint doi: https://doi.org/10.1101/2021.03.08.21253112; this version posted March 8, 2021. The copyright holder for this preprint (which was not certified by peer review) is the author/funder, who has granted medRxiv a license to display the preprint in perpetuity.

It is made available under a CC-BY 4.0 International license .

imposed-on-covid-19-patients-with-learning-difficulties

16. Immunisation against Infectious Disease: The Green Book. Vol Chapter 14a.; 2021. https://assets.publishing.service.gov.uk/government/uploads/system/uploads/attachme nt_data/file/955548/Greenbook_chapter_14a_v6.pdf

17. Priority Groups for Coronavirus (COVID-19) Vaccination: Advice from the JCVI, 30 December 2020. Department of Health and Social Care; 2020. Accessed March 3, 2021. https://www.gov.uk/government/publications/priority-groups-for-coronaviruscovid-19-vaccination-advice-from-the-jcvi-30-december-2020

18. NHS Digital. Secondary Uses Service (SUS). Published December 14, 2020. https://digital.nhs.uk/services/secondary-uses-service-sus

19. Riley S, Ainslie KEC, Eales O, et al. High prevalence of SARS-CoV-2 swab positivity and increasing $R$ number in England during October 2020: REACT-1 round 6 interim report. medRxiv. Published online January 1, 2020:2020.10.30.20223123. doi:10.1101/2020.10.30.20223123

20. GOV.UK. Coronavirus (COVID-19) in the UK. Published March 7, 2021. Accessed March 8, 2021. https://coronavirus.data.gov.uk/details/deaths

21. Bhaskaran K, Bacon S, Evans S, et al. Factors associated with deaths due to COVID19 versus other causes: population-based cohort analysis of UK primary care data and linked national death registrations within the OpenSAFELY platform. medRxiv. Published online January 1, 2021:2021.01.15.21249756. doi:10.1101/2021.01.15.21249756

22. Public Health England. COVID-19: deaths of people with learning disabilities. Published November 12, 2020. Accessed March 3, 2021. https://www.gov.uk/government/publications/covid-19-deaths-of-people-with-learningdisabilities

23. Swann OV, Holden KA, Turtle L, et al. Clinical characteristics of children and young people admitted to hospital with covid-19 in United Kingdom: prospective multicentre observational cohort study. BMJ. 2020;370:m3249. doi:10.1136/bmj.m3249

24. Duarte-Salles T, Vizcaya D, Pistillo A, et al. Baseline characteristics, management, and outcomes of 55,270 children and adolescents diagnosed with COVID-19 and 1,952,693 with influenza in France, Germany, Spain, South Korea and the United States: an international network cohort study. MedRxiv Prepr Serv Health Sci. Published online October 30, 2020:2020.10.29.20222083. doi:10.1101/2020.10.29.20222083

25. Götzinger F, Santiago-García B, Noguera-Julián A, et al. COVID-19 in children and adolescents in Europe: a multinational, multicentre cohort study. Lancet Child Adolesc Health. 2020;4(9):653-661. doi:10.1016/S2352-4642(20)30177-2

26. Williams N, Radia T, Harman K, Agrawal P, Cook J, Gupta A. COVID-19 Severe acute respiratory syndrome coronavirus 2 (SARS-CoV-2) infection in children and adolescents: a systematic review of critically unwell children and the association with underlying comorbidities. Eur J Pediatr. 2021;180(3):689-697. doi:10.1007/s00431-02003801-6

27. Public Health England. JCVI advises inviting people on Learning Disability Register for vaccine. Published February 24, 2021. Accessed March 4, 2021. https://www.gov.uk/government/news/jcvi-advises-inviting-people-on-learning-disabilityregister-for-vaccine

28. Lorenz-Dant K. A brief overview of the current German COVID-19 vaccination strategy. Published December 18, 2020. https://tccovid.org/2020/12/18/a-brief-overview-of-thecurrent-german-covid-19-vaccination-strategy/

29. Dooling K, Marin M, Wallace M, McClung N, et al. The Advisory Committee on Immunization Practices' Updated Interim Recommendation for Allocation of COVID-19 Vaccine - United States, December 2020, Centres for Disease Control and Prevention. https://www.cdc.gov/mmwr/volumes/69/wr/mm695152e2.htm?s_cid=mm695152e2_w\# T1_down

30. ONS. Updated estimates of coronavirus (COVID-19) related deaths by disability status, 
medRxiv preprint doi: https://doi.org/10.1101/2021.03.08.21253112; this version posted March 8, 2021. The copyright holder for this preprint (which was not certified by peer review) is the author/funder, who has granted medRxiv a license to display the preprint in perpetuity.

It is made available under a CC-BY 4.0 International license.

England: 24 January to 20 November 2020. Published February 11, 2021. Accessed March 3, 2021.

https://www.ons.gov.uk/peoplepopulationandcommunity/birthsdeathsandmarriages/deat hs/articles/coronaviruscovid19relateddeathsbydisabilitystatusenglandandwales/24janua ryto20november2020

31. NHS Digital. BETA - Data Security Standards - NHS Digital.. Accessed April 30, 2020. https://digital.nhs.uk/about-nhs-digital/our-work/nhs-digital-data-and-technologystandards/framework/beta---data-security-standards

32. NHS Digital. Data Security and Protection Toolkit - NHS Digital. Accessed April 30, 2020. https://digital.nhs.uk/data-and-information/looking-after-information/data-securityand-information-governance/data-security-and-protection-toolkit

33. NHS Digital. ISB1523: Anonymisation Standard for Publishing Health and Social Care Data - NHS Digital. Accessed April 30, 2020. https://digital.nhs.uk/data-andinformation/information-standards/information-standards-and-data-collections-includingextractions/publications-and-notifications/standards-and-collections/isb1523anonymisation-standard-for-publishing-health-and-social-care-data

34. Secretary of State for Health and Social Care - UK Government. Coronavirus (COVID19): notification to organisations to share information. 2020.

https://web.archive.org/web/20200421171727/https://www.gov.uk/government/publicati ons/coronavirus-covid-19-notification-of-data-controllers-to-share-information 
medRxiv preprint doi: https://doi.org/10.1101/2021.03.08.21253112; this version posted March 8, 2021. The copyright holder for this preprint (which was not certified by peer review) is the author/funder, who has granted medRxiv a license to display the preprint in perpetuity.

It is made available under a CC-BY 4.0 International license.

Table 1. Baseline characteristics of individuals 16 years and older

\begin{tabular}{|c|c|c|}
\hline Characteristic & $\begin{array}{c}\text { On the learning } \\
\text { disability register } \\
N(\%)\end{array}$ & $\begin{array}{l}\text { Not on the } \\
\text { learning disability register } \\
N(\%)\end{array}$ \\
\hline Total & $90,095(100)$ & $14,211,320(100)$ \\
\hline \multicolumn{3}{|l|}{ Agegroup $^{a}$} \\
\hline $16-<45$ & $52,120(58)$ & $6,355,662(45)$ \\
\hline $45-<65$ & $29,100(32)$ & $4,629,591(33)$ \\
\hline $65-<70$ & $3,881(4)$ & $888,739(6)$ \\
\hline $70-<75$ & $2,705(3)$ & $894,454(6)$ \\
\hline $75-<80$ & $1,370(2)$ & $622,363(4)$ \\
\hline $80+$ & $919(1)$ & $820,511(6)$ \\
\hline Female & $36,702(41)$ & $7,350,940(52)$ \\
\hline Male & $53,393(59)$ & $6,860,380(48)$ \\
\hline \multicolumn{3}{|l|}{ Ethnicity } \\
\hline White & $81,104(90)$ & $12,039,335(85)$ \\
\hline Black & $1,715(2)$ & $402,038(3)$ \\
\hline South Asian & $5,445(6)$ & $1,174,749(8)$ \\
\hline Mixed & $1,125(1)$ & $206,754(1)$ \\
\hline Other & $706(1)$ & $388,444(3)$ \\
\hline \multicolumn{3}{|l|}{ Region } \\
\hline East & $18,379(20)$ & $3,283,255(23)$ \\
\hline London & $3,631(4)$ & $1,166,640(8)$ \\
\hline $\begin{array}{l}\text { Midlands } \\
\text { North East, Yorkshire and the }\end{array}$ & $21,529(24)$ & $3,157,325(22)$ \\
\hline Humber & $19,593(22)$ & $2,712,531(19)$ \\
\hline North West & $10,193(11)$ & $1,243,992(9)$ \\
\hline South East & $5,229(6)$ & $855,933(6)$ \\
\hline South West & $11,541(13)$ & $1,791,644(13)$ \\
\hline \multicolumn{3}{|l|}{ Index of multiple deprivation } \\
\hline 1 (Least deprived) & $9,677(11)$ & $2,801,547(20)$ \\
\hline 2 & $13,799(15)$ & $2,893,839(20)$ \\
\hline 3 & $17,042(19)$ & $2,861,727(20)$ \\
\hline 4 & $21,566(24)$ & $2,877,708(20)$ \\
\hline 5 (Most deprived) & $28,011(31)$ & $2,776,499(20)$ \\
\hline \multicolumn{3}{|l|}{ Learning disability and related } \\
\hline Mild-moderate learning disability & $73,980(82)$ & - \\
\hline Severe-profound learning disability & $16,115(18)$ & - \\
\hline Not in residential care & $82,068(91)$ & $14,209,944(>99)$ \\
\hline Residential care & $8,027(9)$ & $1,376(<1)$ \\
\hline No Down's syndrome & $82,971(92)$ & $14,210,422(>99)$ \\
\hline Down's syndrome & $7,124(8)$ & $898(<1)$ \\
\hline No Cerebral Palsy & $83,182(92)$ & $14,199,969(>99)$ \\
\hline Cerebral Palsy & $6,913(8)$ & $11,351(<1)$ \\
\hline \multicolumn{3}{|l|}{ Comorbidities } \\
\hline BMI>40 (Obese III) & $5,911(7)$ & $382,436(3)$ \\
\hline
\end{tabular}


medRxiv preprint doi: https://doi.org/10.1101/2021.03.08.21253112; this version posted March 8, 2021. The copyright holder for this preprint (which was not certified by peer review) is the author/funder, who has granted medRxiv a license to display the preprint in perpetuity.

It is made available under a CC-BY 4.0 International license .

\begin{tabular}{|c|c|c|}
\hline Asthma (with OCS use) & $878(1)$ & $129,409(1)$ \\
\hline Cystic fibrosis & $35(<1)$ & $3,733(0)$ \\
\hline Respiratory disease & $3521(4)$ & $574,188(4)$ \\
\hline Chronic cardiac disease & $5,642(6)$ & $915,275(6)$ \\
\hline Atrial fibrillation & $2,313(3)$ & $507,129(4)$ \\
\hline $\begin{array}{l}\text { Deep vein thrombosis/ } \\
\text { Pulmonary embolism }\end{array}$ & $2,075(2)$ & $291,614(2)$ \\
\hline \multicolumn{3}{|l|}{ Diabetes } \\
\hline With $\mathrm{HbA} 1 \mathrm{c}<58 \mathrm{mmol}$ mol-1 & $6,794(8)$ & $852,854(6)$ \\
\hline With $\mathrm{HbA} 1 \mathrm{c} \geq 58 \mathrm{mmol} \mathrm{mol}-1$ & $3,425(4)$ & $400,577(3)$ \\
\hline With no recent $\mathrm{HbA} 1 \mathrm{c}$ measure & $1,324(1)$ & $159,392(1)$ \\
\hline Liver disease & $461(1)$ & $85,489(1)$ \\
\hline Stroke & $1,965(2)$ & $286,782(2)$ \\
\hline Transient Ischaemic Attack & $933(1)$ & $216,932(2)$ \\
\hline Dementia & $1,895(2)$ & $168,852(1)$ \\
\hline Other neurological disease & $8,816(10)$ & $129,587(1)$ \\
\hline \multicolumn{3}{|l|}{ Reduced kidney function } \\
\hline Stage $3 a / 3 b$, eGFR $30-60$ & $2,827(3)$ & $714,068(5)$ \\
\hline Stage $4 / 5$, eGFR<30 & $521(1)$ & $68,475(<1)$ \\
\hline Dysplenia & $142(<1)$ & $23,042(<1)$ \\
\hline Organ transplant & $191(<1)$ & $12,969(<1)$ \\
\hline $\begin{array}{l}\text { Conditions leading to } \\
\text { immunosuppression }\end{array}$ & $483(1)$ & $40,744(<1)$ \\
\hline \multicolumn{3}{|l|}{ Haematological malignancy } \\
\hline Diagnosed last year & $25(<1)$ & $7,130(<1)$ \\
\hline Diagnosed $2-5$ years ago & $79(<1)$ & $21,655(<1)$ \\
\hline Diagnosed $>5$ years ago & $284(<1)$ & $49,514(<1)$ \\
\hline $\begin{array}{l}\text { Cancer (non-haematological) in last } \\
\text { year }\end{array}$ & $195(<1)$ & $62,859(<1)$ \\
\hline RA/SLE/psoriasis & $4,272(5)$ & $710,001(5)$ \\
\hline Inflammatory bowel disease & $866(1)$ & $178,662(1)$ \\
\hline Serious mental illness & $8,015(9)$ & $168,213(1)$ \\
\hline
\end{tabular}

${ }^{a}$ See Table 2 for characteristics of those under 16 years old 
medRxiv preprint doi: https://doi.org/10.1101/2021.03.08.21253112; this version posted March 8, 2021. The copyright holder for this preprint (which was not certified by peer review) is the author/funder, who has granted medRxiv a license to display the preprint in perpetuity.

It is made available under a CC-BY 4.0 International license.

Table 2. Baseline characteristics of individuals under 16 years old

\begin{tabular}{|c|c|c|}
\hline Characteristic & $\begin{array}{c}\text { On the learning } \\
\text { disability register } \\
N(\%)\end{array}$ & $\begin{array}{c}\text { Not on the } \\
\text { learning disability register } \\
N(\%)\end{array}$ \\
\hline Total & $9,114(100)$ & $2,615,239(100)$ \\
\hline Female & $2,965(33)$ & $1,275,295(49)$ \\
\hline Male & $6,149(67)$ & $1,339,944(51)$ \\
\hline \multicolumn{3}{|l|}{ Ethnicity } \\
\hline White & $6,971(76)$ & $2,070,441(79)$ \\
\hline Black & $369(4)$ & $96,159(4)$ \\
\hline South Asian & $1,256(14)$ & $277,942(11)$ \\
\hline Mixed & $299(3)$ & $99,477(4)$ \\
\hline Other & $219(2)$ & $71,220(3)$ \\
\hline \multicolumn{3}{|l|}{ Region } \\
\hline East & $1,743(19)$ & $618,596(24)$ \\
\hline London & $552(6)$ & $167,325(6)$ \\
\hline $\begin{array}{l}\text { Midlands } \\
\text { North East. Yorkshire and the }\end{array}$ & $2,188(24)$ & $608,128(23)$ \\
\hline Humber & $2,050(22)$ & $493,649(19)$ \\
\hline North West & $966(11)$ & $224,103(9)$ \\
\hline South East & $566(6)$ & $169,577(6)$ \\
\hline South West & $1,049(12)$ & $333,861(13)$ \\
\hline \multicolumn{3}{|l|}{ Index of multiple deprivation } \\
\hline 1 (Least deprived) & $1,215(13)$ & $485,858(19)$ \\
\hline 2 & $1,383(15)$ & $471,778(18)$ \\
\hline 3 & $1,584(17)$ & $483,503(18)$ \\
\hline 4 & $2,069(23)$ & $533,144(20)$ \\
\hline 5 (Most deprived) & $2,863(31)$ & $640,956(25)$ \\
\hline \multicolumn{3}{|l|}{ Learning disability and related } \\
\hline Mild-moderate learning disability & $7,740(85)$ & - \\
\hline Severe-profound learning disability & $1,374(15)$ & - \\
\hline Not in residential care & $9,054(99)$ & $2,615,192(>99)$ \\
\hline Residential care & $60(1)$ & $47(>1)$ \\
\hline No Down's syndrome & $8,207(90)$ & $2,613,511(>99)$ \\
\hline Down's syndrome & $907(10)$ & $1,728(<1)$ \\
\hline No Cerebral Palsy & $8,614(95)$ & $2,611,120(>99)$ \\
\hline Cerebral Palsy & $500(5)$ & $4,119(<1)$ \\
\hline \multicolumn{3}{|l|}{ Comorbidities } \\
\hline BMI>40 (Obese III) & $70(1)$ & $4408(<1)$ \\
\hline
\end{tabular}


Table 3. Estimated hazard ratios for COVID-19 outcomes among adults 16 years and over, adjusted for potential confounders (age, sex, ethnicity, geographical region)

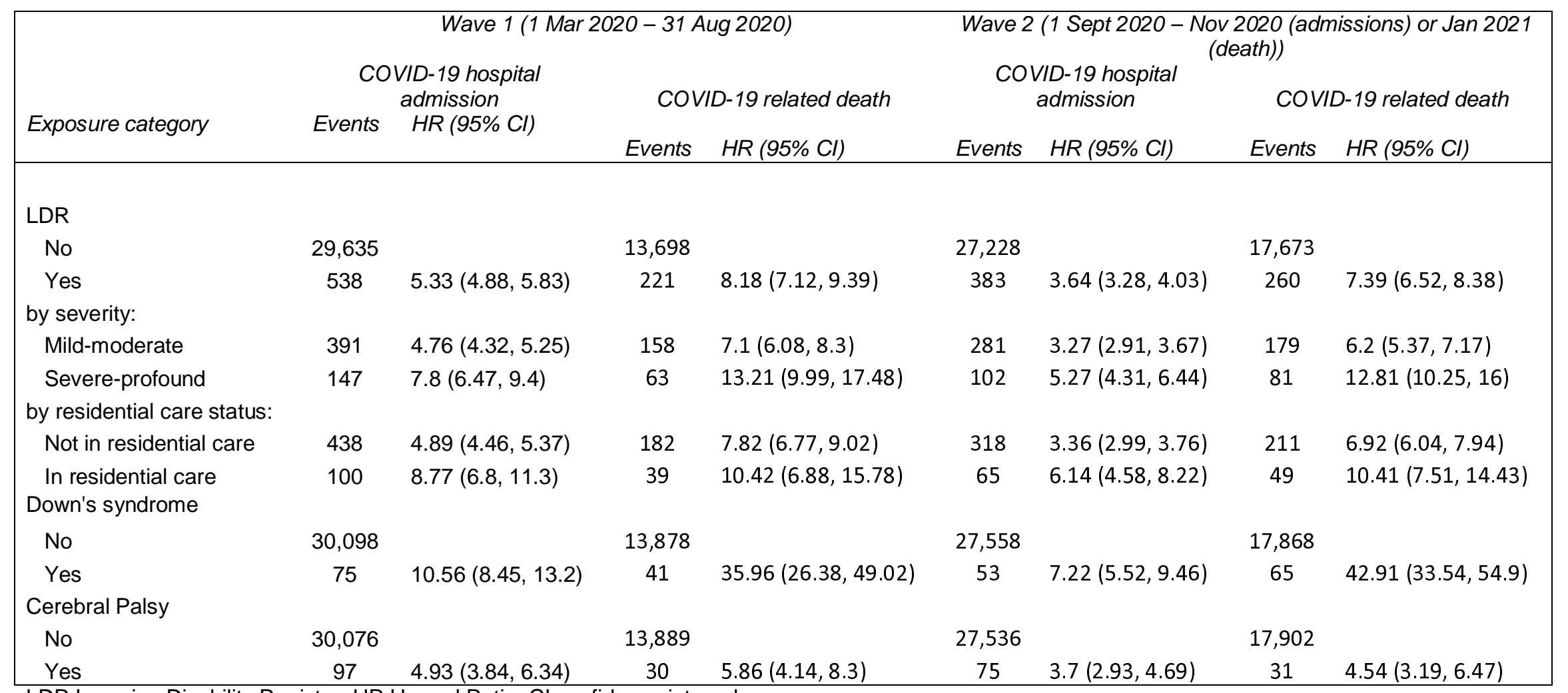

LDR Learning Disability Register; HR Hazard Ratio; Cl confidence interval 
medRxiv preprint doi: https://doi.org/10.1101/2021.03.08.21253112; this version posted March 8, 2021. The copyright holder for this preprint (which was not certified by peer review) is the author/funder, who has granted medRxiv a license to display the preprint in perpetuity.

It is made available under a CC-BY 4.0 International license .

Figure 1: Cumulative (a) COVID-19 mortality and (b) COVID-19 hospital admission or mortality for individuals on the learning disability register and not with $95 \% \mathrm{Cl}$, standardised by age, sex and ethnicity, among individuals 16 years and above through the two waves 0 infection. 


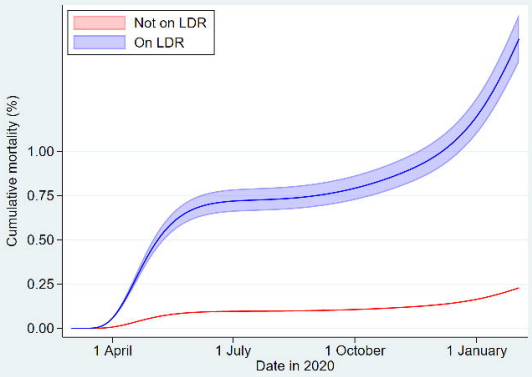




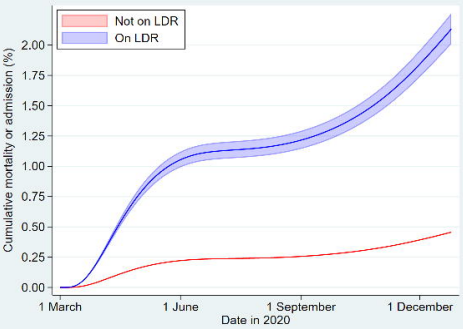

